\title{
1 Introduction: the PPP phenomenon and its evaluation
}

\author{
Graeme A. Hodge, Carsten Greve and \\ Anthony E. Boardman
}

\section{Introduction}

There has been much debate about public-private partnerships (PPPs) over the past few decades. Indeed, the whole partnership movement has become increasingly professionalized, technical and rational. But beneath the veneer, a paradox remains. Despite its popularity and its iconic status as a visible pillar of contemporary public management practices, the PPP phenomenon remains an enigma. We still debate its definition, its historical origins and the degree to which it constitutes a genuinely new policy delivery solution to the provision of public infrastructure. We still debate why, if it is simply a modest evolution from traditional delivery techniques, some jurisdictions have taken on PPPs with enthusiasm while others have not. And we still debate the degree to which the real challenges faced by PPPs are not the technical complexity first evident, but the accusations of 'illegitimacy' that remain, ${ }^{1}$ as well as concerns about the crucial governance challenges current governments are now placing on future generations through long-term contracts. In other words, despite the popularity of the partnership talk, we have yet to agree on just what PPPs actually are, and whether they are really a 'revolution' in thinking or just another fashionable business idea sold to us from the 'smartest guys in the room'.2

In thinking through this paradox, it is essential to work out just exactly what is new. With public infrastructure provision, for example, most governments around the world have for years made decisions about large-scale public infrastructure projects with long lives, have dealt with complex policy matters, and have worked with the private sector to build and develop infrastructure. So the challenge of infrastructure development has always, in a sense, been a central part of the democratic governance project. And as a consequence, it has by definition attracted political controversy. Indeed, many of the concerns voiced about modern PPP infrastructure projects are not new at all. What does appear to be new in these modern PPPs, however, is the preference often to use private finance arrangements, the highly complex contractualization of 'bundled' 
infrastructure arrangements, and altered governance and accountability assumptions. $^{3}$

There is none the less little doubt that PPPs are an important part of government in the modern age. That is the justification for this international handbook. But to understand them, we need to retrace a few steps. First, there is a need to establish some modest definitions and boundaries. We need to characterize the PPP phenomenon as the multidisciplinary animal it is and to note some of the useful cross-disciplinary lenses that might help our investigations. Second, we then need to propose some important conceptual frameworks that will both assist in the successful delivery of PPPs as well as help our evaluation of the degree to which PPPs meet the objectives sought for them. This initial chapter aims to fulfil both these needs.

This initial handbook chapter adopts a 'sober reflection' philosophy similar to David Parker's earlier paper contemplating the UK's privatization experience (Parker, 2004). This handbook looks overall at the global experience of one particular form of partnership arrangement - that of long-term infrastructure contracts. As a consequence, this chapter first defines the PPP phenomenon and notes that infrastructure provision is one member of several PPP 'families'. It then outlines the multiple stakeholders and disciplines interested in PPPs and acknowledges a range of evaluation challenges this brings. Next, the chapter puts one eye to the future and articulates some of the crucial agenda items likely for partnerships. Finally, we set out the structure of this book and outline the contributions made by our team of international authors.

\section{The PPP phenomenon}

In some ways, neither the global spread of PPPs nor their popularity in government are a surprise. PPPs are a classic public policy issue. They are simultaneously a form of governance, a public policy delivery tool and a language-game involving multiple grammars. ${ }^{4}$ So they are a political tool, a technical phenomenon and a rhetorical framing device for governments. But, more importantly, they remain slippery and defy repeated attempts to characterize and explain them simply.

Thinking further about these definitional issues, PPPs are loosely defined as cooperative ${ }^{5}$ institutional arrangements between public and private sector actors. But this of course covers a wealth of possibilities. Governments have long had some degree of public sector and private sector cooperation over the centuries (Wettenhall, 2003, 2005). And in any event, history also brings with it both the good news of economic growth and the bad. On the one hand it is true, for example, that privateer shipping underpinned the historical growth and dominance of the British 
global economic empire, and public-private cooperation saw completion of the modern dream of the Channel Tunnel between England and France. On the other hand, however, privateer shipping was a 'feeble and corrupt system' where leading officials promoted partnership ventures with a 'motive of plunder', and the fragile financial position of the Channel Tunnel has now left citizens, governments and private investors all with huge uncertainties and losses. Arguments over efficiency, service quality and accountability in the two sectors have certainly been 'well rehearsed'6 over centuries.

Governments always play language-games. To a large degree it is the very nature of political communication. What we choose to emphasize, how this is characterized and the word-pictures we present to others in our discussions all amount to a language-choice. Those supporting PPPs tend to emphasize the positive parts of past government-business interactions and characterize today's PPPs as simply an extension of historical economic development. For example, legal contracts are labelled 'partnerships' rather than 'commercial deals', and privatized finance is labelled a 'partnership arrangement' rather than a 'mega-credit card' to which governments sign up. On the other hand, those critical of today's PPPs emphasize the negative parts of past government-business interactions and call for corruption failures, for example, not to be repeated. Language-games are clearly applied every day to the PPP phenomenon. And in the land of claims and counter-claims during public policy debates, such language-games do indeed matter. ${ }^{7}$

Of equal importance is the governance perspective, that is, viewing PPPs as 'an organizational and financial arrangement'. This includes, for example, institutional marriages, such as the definition of Van Ham and Koppenjan (2001), or contractual arrangements tying institutions together and legally sharing risks and returns (Osborne, 2001; Grimsey and Lewis, 2004). ${ }^{8}$

Conceptually, there are five different families of possible partnerships (Hodge and Greve, 2007):

1. Institutional cooperation for joint production and risk sharing (such as the Netherlands Port Authority)

2. Long-term infrastructure contracts (LTICs), which emphasize tight specification of outputs in long-term legal contracts (as exemplified in UK Private Finance Initiative (PFI) projects)

3. Public policy networks (in which loose stakeholder relationships are emphasized)

4. Civil society and community development

5. Urban renewal and downtown economic development (and where, in 
the USA, a portfolio of local economic development and urban regrowth measures is pursued).

These five PPP families ${ }^{9}$ cover an array of governance types and are clearly more than just the PFI experience of the UK or the urban renewal practices of the USA. Indeed, they cover many potential institutional arrangements as well as numerous contract arrangements, including 'alliance' forms of contract. ${ }^{10}$

\section{Defining LTIC-type PPPs}

This handbook aims to provide a guide to a range of readers: expert practitioners; interested lay readers; academics across several fields; and students of government-business relationships. As well as providing guidance on the intellectual underpinnings of today's PPPs, their rationale(s) and their logistics, this project also aims to make progress in assessing the merits of PPPs. Such an evaluation is a large undertaking and, as with any public policy arena, it is also a sensitive one. If we were to mount an evaluation of our experience to date with LTIC-type PPPs as one strand of the above-mentioned PPP families, there would be many pitfalls to watch out for. A necessary foundation, though, would be questions of definition. What exactly are LTIC-type PPPs? Which perspectives might be most helpful in considering the worth of this phenomenon? Which institutional options seem to perform best? And what evaluation approaches might be most useful here?

The single family of LTIC-type PPPs is itself a large group. Campbell (2001, p. 1), for instance, suggested that an LTIC-type 'PPP project generally involves the design, construction, financing and maintenance (and in some cases operation) of public infrastructure or a public facility by the private sector under a long term contract'. But there are many different possible PPP definitions across different public-private mixes, and previous books on PPPs over the past decade have covered a multitude of these. ${ }^{11}$ We will not repeat them all here. ${ }^{12}$ It is sufficient to acknowledge that LTICs cover a wide range of possibilities. Conceptually, there is a continuum of options ranging from a public emphasis at one extreme to a private emphasis at the other. ${ }^{13}$ These arrangements include, for example, the O\&M (operations and maintenance) contract, BOOT (build, own, operate, transfer), BTO (build, transfer, operate), WAA (wrap-around addition), and DBFO (design, build, finance, operate), along with a host of other acronyms. In fact, there are many possible combinations of activities such as design, finance, operate, maintain, own, transfer, lease, develop and buy (Zarco-Jasso, 2005). LTIC-type PPPs clearly represent many contractual types depending on the degree 
to which different activities are undertaken by the public or private sectors. ${ }^{14}$

It is important to understand that the contractual types being adopted under the PPP banner also depend on the policy and ideological persuasions of governments signing PPPs. For example, a major strength of PPPs appears to be that a wide range of infrastructure services can be specified in detail and bundled together as one big package for the winning consortium to deliver. This idea, which has evolved since the 1980s, has often enabled governments to 'crash' through policy inertia and policy disinterest, and allow policy arenas such as major new toll roads, school or hospital renewal and maintenance programmes, to get clearer approval as high political priorities. In other words, using bundled arrangements as a governance tool to attract policy approval has demonstrated real political merit. But under PFI-type policies such as those of the UK or copied elsewhere (such as Partnerships Victoria, in Australia), this bundling idea itself has been glued together with the assumption that private finance must somehow be the basis for such deals. ${ }^{15}$ Missing from such practice has been the explicit recognition that PPPs may be as much a statement of government policy and a builder of symbolic relationships with the financial sector as they are a logistical or technical delivery mechanism for infrastructure projects.

There is certainly a huge amount of money at stake in today's PPPs. Blanc-Brude et al. (2007), for instance, report that for LTIC-type PPPs alone, the past 15 years in Europe has seen more than 1000 contracts at a capital value of almost $€ 200$ billion. IFSL Research (2008) also report more recent data showing that over the seven-year period 2001-07, PPPs have mainly been of macroeconomic and systemic importance in the UK (with 57.1 per cent of project expenditure), Spain (at 5.6 per cent), Italy (at 4.8 per cent) and Ireland (at 4.0 per cent), with a total of 694 projects throughout Europe involving deals of $€ 73821$ million. Moreover, they are now also apparently spreading from traditional sectors such as transport, health and education into other fields including information technology, waste management and water. ${ }^{16}$ In terms of professional experience and capability, the UK remains the intellectual leader. ${ }^{17}$

\section{Multiple stakeholders and PPP cross-disciplinarity}

The PPP discourse and evaluation space is filled with many different interest groups. Advocates include consultants, merchant bankers, legal firms and construction companies. Those involved directly in the financial transactions, not surprisingly, often speak highly of them. One such project leader explained to one of the authors of this chapter that because these new PPP arrangements enabled $\$ 1$ billion to be spent on infrastructure in 
the coming year compared to only $\$ 130$ million in the previous 12-month period, the new arrangements were therefore some eight times better than the old! Governments, too, have also been among the most ardent advocates, through Ministers and their compliant Treasury and Finance Departments. ${ }^{18}$ But PPPs have never been smooth waters to sail in, if we learn anything from history. High expectations about the formation of PPPs have often resulted in inadequate methods of interaction between public sector and private organizations (Koppenjan, 2005). Numerous faults can occur in these relationships, and critics have appeared across disciplines and across traditional ideological borders.

One implication is that a modern review of PPPs must be undertaken by those who clearly do not have conflicting interests - possibly taking a percentage of revenue from transactions as they pass through. Advocating governments face a conflict of interest as their own policy priorities and preferences are subject to assessment. Consulting businesses claim to provide balanced evaluations of PPP policy options through their professional reports, while simultaneously and openly discussing 'deal-flow' because of its importance to their core revenues. PricewaterhouseCoopers (2005), for example, see PPPs as sophisticated best practice and as 'delivering the PPP promise' . . . through 'connected thinking', while Ernst \& Young (2007) view PPPs as having 'provided value to the Government and public sector'. But acknowledging conflicts of interest and governing them successfully is no small matter. Global consulting groups are now both influential and powerful. A few years ago, the global consulting sector employed some 463000 employees across 123 countries, with revenues estimated at a total of $\$ 170$ billion per annum. ${ }^{19}$ These days, global consulting revenues are probably closer to around US\$192 billion. And while governments use consultants as much as the other way around, the conflicts of interest between traditional business owners and those of governments have now become more blurred and more difficult to discern. As a consequence, such conflicts in policy arenas such as PPPs have also now become more difficult to avoid. In any event, powerful PPP lobby groups clearly exist.

What is also clear from the discussion thus far is that the PPP phenomenon is not limited to a particular discipline. In terms of the LTIC arena, for instance, legal contracts certainly form the basis of the agreements between parties. But both the manner in which government decisions to enter such contracts are made as well as the content of such contracts are clearly not simply legal matters. They are social and inherently political matters of public importance. Similarly, complex financing, costing and pricing matters are not limited to the interests of finance or accounting, but are also matters for public debate and scrutiny. Commercial arrangements 
entered into for three or four decades will affect future generations and may limit their ability to make other decisions. These issues are not simply matters for consulting firms, construction engineering companies and corporate lawyers, but are inherently matters of governance and citizen expectations. The point here is that a wide range of disciplines is relevant to any examination of PPPs. It is little surprise, then, that this book is, as a consequence, multidisciplinary in nature.

All this is especially important as PPPs threaten to evolve in new directions. The global economy will get back on its feet and economic growth will remain an important policy priority for most world governments. But communities will struggle to rebuild trust in global markets. Recent experience has revealed the negative results of widespread systematic trading in complex financial deals with little real knowledge of the riskiness of these deals. Lucrative profits went to some cunning players and company executives. Trust was taken for granted, and losses were passed along the line to those less well informed. None the less, rebuilding global financial trust will no doubt occur in time, and the desire for trusted 'partnerships' between governments and business is likely to continue. Throughout history, governments in nearly every country have had a fundamental role in development of the nation state, including its physical, social and legal infrastructure. ${ }^{20}$ Recently, most major governments have indicated a willingness to invest in new infrastructure in order to stimulate their economies. PPPs will inevitably continue to be promoted as having much potential to demonstrate government-business cooperation. However, the traditional role of government is also likely to be rediscovered over the coming years as market instabilities continue. Also, partnerships are likely to reappear in new guises and take new directions and forms, such as alliance contracts.

What will be constant, however, will be the need for careful examination of the PPP phenomenon and the common ground between public and private actors, whatever the exact government-business relationship. As Lindblom (1959) said, in any Western liberal economy, real power will continue to be held by the government and the business sector. So, in a sense, the desire for ongoing relationships between business and government is no real surprise. But citizens will also continue to remain sensibly sceptical of overblown policy promises from elected representatives. The global spread of privatization policies saw huge differences between the multiple lofty political promises of efficiency, lower prices and improved market choices, and the reality that there have been as many lessons in retrospect as there have been obvious success stories. And in any event, such success stories were usually delivered only when governments focused their efforts on regulating carefully and strongly to ensure that the new businesses did 
not take undue advantage of citizens. Gains to citizens did not appear of their own volition through any inherent superior private sector performance (Hodge, 2000). Other fields too, remind us of similarly overblown promises. Genetically modified crops, according to former US president George Bush Jr and biotech companies, were going to 'end world hunger', and the information and communication revolution was going to put the world on the 'information superhighway' (Rayner, 2004). In reality, world hunger has continued under the weight of the international political economy, underpinned by personal indifference and selfishness. Likewise, the global 'digital divide' and the need to protect youngsters from a net full of pornography is now as much the topic of conversation as the promised gift of a superhighway. Policy promises involving public and private ideologies are often much more optimistic than the new reality.

\section{Evaluating PPPs}

A key task of this handbook will be to evaluate our PPP experience to date. But this is no easy task, as evaluation usually means many things to many people. For a start, evaluations can vary in strength, from personal impressions and 'back-of-the-envelope' assessments at one extreme, to more systematic and comprehensive studies using statistical principles and control methods at the other. They can also be undertaken for quite different reasons, such as the narrow perspective of improving PPP delivery processes and organizational learning, through to the broader perspective of assessing public policies themselves. Of course PPPs also have a wide range of objectives, ranging from the desire to remove infrastructure projects off government balance sheets to arguments around better value for money (VfM) and delivering superior on-time and on-budget performance. Several other objectives have also been proposed by various governments. A huge range of evaluation approaches is possible for any one particular objective. We shall return to this central issue in Chapter 5 of this handbook as we contemplate paths towards more evidence-based partnership policies. For the moment, however, setting out some primary dimensions that might underpin any evaluation of PPPs would seem sensible.

Policy alternatives can be evaluated using multi-goal analysis (Weimer and Vining, 2004). Weimer and Vining suggest four broad goals for government: allocative efficiency; equity (distribution); government budget impact; and politics. Focusing on the assessment of activities involving the public and private sectors, Hodge (2000) alternatively proposes evaluation using political, economic/financial and social goals. ${ }^{21}$ Adopting these three broad dimensions, we could evaluate a PPP according to its impact of each goal for each of the three classic sectors: government, the business sector and the community. ${ }^{22}$ This is illustrated in Table 1.1. 
Table 1.1 Conceptual framework for evaluating PPPS

\begin{tabular}{llcc}
\hline Goals & \multicolumn{3}{c}{ Stakeholders } \\
\cline { 2 - 4 } & A Government & B Business & $\begin{array}{c}\text { C Citizens/ } \\
\text { community }\end{array}$ \\
\hline 1. $\begin{array}{l}\text { Political/ } \\
\text { governance }\end{array}$ & $+/-$ & $+/-$ & $+/-$ \\
2. $\begin{array}{l}\text { Economic/ } \\
\text { financial }\end{array}$ & $+/-$ & $+/-$ & $+/-$ \\
3. Social & $+/-$ & $+/-$ & $+/-$ \\
\hline
\end{tabular}

This table shows, for example, that if a PPP were to be assessed against a government financial objective, such as the need to deliver an infrastructure project with no cost to its budget, then this assessment would occur in cell 2A. If we also wanted to consider the financial impact of this project (whether positive or negative) on stakeholders in the business sector and on consumers, we would need to examine cells $2 \mathrm{~B}$ and $2 \mathrm{C}$ respectively as well. If we wanted a full multi-goal analysis, we would have to consider all cells.

It would be possible, of course, to make finer distinctions within each stakeholder group in order to study distributional implications in more detail. For example, government might be broken down into local or national, business might be broken down into PPP contractors or other businesses, and citizens could be subdivided into users or non-users.

Having said this, it is important to acknowledge that both PPP projects themselves as well as the PPP project delivery mechanism ought to be subject to evaluation. This handbook will focus primarily on reviewing PPPs as an infrastructure delivery mechanism, however, rather than assessing actual infrastructure projects themselves.

\section{Structure of the book}

In the context of these observations, this book seeks to provide an international perspective that makes a new contribution to our knowledge of PPPs. Whether we view them as an engineering tool, as a governance mechanism or as a public policy phenomenon, all cry out for clearer thinking and wiser evaluation of our experience to date.

Also, we should have an eye to the future in terms of crucial agenda items for this phenomenon. A renewed PPP research agenda might encapsulate a wide range of continuing sociopolitical as well as technical issues. Nine research domains seem apposite: 


\section{International handbook on public-private partnerships}

1. The merit/worth of LTIC PPPs

2. The circumstances when they may give highest VfM and innovation

3. The circumstances when they may act as a better governance tool

4. How we can in future better regulate PPPs in the public interest

5. The role and findings of auditors general to date

6. Why their promotion 'succeeds' in some jurisdictions but not in others

7. What is the nature and consequence of the global PPP industry?

8. What is the place of PPPs in the context of development?

9. What is the next chapter for PPPs and the implications of this?

By way of structure, this book proceeds by following four themes: underpinning intellectual PPP foundations; a range of lenses central to each of the disciplines; our international empirical experience to date; and future issues. The first theme, beginning with this introductory chapter, covers historical views of PPPs, in terms of both observations that might be made of partnerships through time and the more recent intellectual foundations of the movement. It also traverses the terrain of language and the multiple grammars of the phenomenon, as well as noting several challenges facing any serious evaluation of PPPs.

The second theme is the disciplines, looking specifically into traditional arenas including politics, economics, engineering, law and accounting. Also included, however, are the newer interest arenas of risk management and governance.

The third theme articulates international empirical experience and has a global reach. It begins with the UK, but also travels to the EU, North America, Asia Pacific and Scandinavia. To provide larger global overviews, we also add the experience of the World Bank and the United Nations.

Crucial issues for the future of the PPP phenomenon are covered by the fourth theme. Here, we analyse the global PPP industry and recent trends towards alliance contracts. Recognizing that the future of PPPs depends on evaluations made of their success or failure, three perspectives of PPP performance are also added, covering both developed and transition economies.

Finally a synthesis of lessons to date is made and some conclusions are articulated.

\section{Conclusions}

Today's PPP phenomenon represents many different public-private arrangements having long historical pedigrees and crossing several professional disciplines. Our debates over LTIC-type PPPs, though, have 
thus far been closer to policy language-game-playing than evidence-based learning and synthesis. Evaluating the degree to which LTIC-type PPPs meet our expectations, however, is not an easy task, and demands a more sober and informed approach than taken to date. Multiple disciplines are involved in PPPs, each with their own emphasis on what is most important. There are also multiple stakeholders and many conflicts of interest buried within evaluation questions.

LTIC-type PPPs will continue to promise advantages to governments and those groups that are part of the PPP industry. And in the face of new market instabilities and our continuing search for economic growth in increasingly uncertain times, PPPs will continue to be put forward as an appropriate method for the delivery of public infrastructure projects and programmes. This handbook seeks not only to articulate the wide range of PPP types and approaches now possible, but also to assess the relative effectiveness of these options and clearly articulate the evidence on which assessments are based. It also seeks to identify new directions that our enquiries ought to be pursuing. The real opportunity here is to re-evaluate our own policy positions on PPPs, rearticulate shared knowledge and insights, and reassess common priorities on where we should turn next in our PPP research and practice. All these challenges offer an exciting international frontier in learning.

\section{Notes}

1. See for example Hodge (2006).

2. These colourful labels have been taken first from Grimsey and Lewis (2004), and second, from the film Enron (Jigsaw Productions, 2005). The second label does not imply illegal activity of businesses engaging in PPPs, of course, but does imply the need to think more carefully about the size of financial rewards, the existence and power of personal and corporate incentives, and the need to be vigilant regarding the price paid and the veracity of arrangements for risks to be 'managed' by others signing up to PPP contract deals. It also expresses strongly the need for far more intelligent regulatory scrutiny in place of blind trust in the re-engineered products sold within modern, and as we now know, imperfect, financial markets.

3. See Hodge (2006). Referring to the work of Parliamentary Committees in Australia, he notes that of the 76 recommendations to improve PPPs, two-thirds of these dealt directly with the three issues of private finance, complexity, and governance and accountability.

4. See Linder (1999).

5. To some scholars, the word 'cooperative' is misplaced here. Even the word 'partnership' should always be in quotation marks, as, to them, it is close to an oxymoron. Such commentators regard the term 'public-private partnership' as a clever marketing ploy by the private sector and government contracting organizations, both of which do very well in terms of strong profits and high salaries. In other words, PPP to these scholars should be more accurately defined as 'mutually beneficial' arrangements as distinct from 'cooperative'.

6. See McIntosh et al. (1997).

7. Previous work from Hodge and Greve (2007) referred, for instance, to the amusing situation in which the same PPP phenomenon was framed in two opposite ways for local 


\section{International handbook on public-private partnerships}

political gain. In the case of Victoria, Australia, the PFI-type PPPs are argued to have nothing to do with privatization and are vigorously separated from this policy. In the UK, however, the Treasury sees the two as inherently connected and speaks of PPPs as directly equivalent to privatization (HM Treasury, 2003).

8. The degree to which PPP is fundamentally seen as being tied together on the basis of either being a joint institution or else through a formal legal contract continues to be a strong thread throughout PPP debates. Differing expectations exist in each of these cases in matters of control, funding, ownership and institutional relationship. Each also implies a different degree of joint-ness and separability.

9. See also Weihe (2005) for her meta-view outlining five alternative PPP 'approaches', namely, local regeneration, policy, infrastructure, governance and development.

10. Most 'alliance' forms of contract include unanimous decision-making protocols, no recourse to the courts for dispute resolution and equal sharing of cost overruns or underruns (Davies, 2008).

11. See, for example, Allan (1989), Savas (2000), Berg et al. (2002), Grimsey and Lewis (2004) or OECD (2008) here.

12. In the EU, the Commission terms infrastructure PPPs 'institutionalized PPPs', but the term is still not legally defined in community law. Instead, the definition of a PPP continues to be interpreted in the light of community law on public procurement and concessions. For more information on PPPs in the EU, visit ec.europa.eu/internal_market/ publicprocurement/ppp_en.htm.

13. OECD (2008, p. 20), for instance, also places PPPs somewhere in the middle of the continuum between purely public and purely private. The five points along this continuum in order of increasing private-ness were complete government production and delivery, traditional public procurement, PPPs, concessions and, lastly, privatization. Alternatively, Grimsey and Lewis (2004, p. 54) nominate some 21 alternative publicprivate business models in between either fully public provision or outright privatization, Savas (2000, p. 241) nominates ten models, and OECD (2008, p. 22) nominates 14 options.

14. Indeed, when thinking simply about the dimensions of PPP control, funding and ownership, some eight combinations of public-private mix are possible (Zarco-Jasso, 2005). These eight combinations are the result of two possible domains (public or private) for each of the three dimensions (control, funding and ownership) making a total of $2 \times 2$ $\times 2=8$

15. Technically, this is purely a policy preference of government. Governments could, if they chose, publicly finance consortia projects through raising bonds, for example, or consider various hybrid financing options going back to the work of Heald (2003). The range of options available here, however, would need to be articulated by sympathetic observers, and away from conflicting interests.

16. IFSL (2008) lists the sector expenditure shares for UK PFI/PPPs (over the period 1987-2006) as being transport (28.4 per cent), health (23.2 per cent), education (15.5 per cent), accommodation (10.7 per cent), defence (10.1 per cent), telecommunications and information technology (4.5 per cent), waste management and water (4.2 per cent), local government ( 1.5 per cent) and other projects ( 1.9 per cent).

17. Interestingly, on the basis of expenditure as a proportion of GDP, PwC (2005, p. 37) suggests that Portugal spends more than double that of the UK. Another basis of ranking might be expenditure per head of population. In this case, Australia appears to lead the pack on the basis of OECD (2008) figures for PPP outlays, spending 6 per cent more than the UK and over double that of Portugal.

18. In some instances, after years of reforms introduced under the banner of 'new public management', such public servants are also on contracts, with an obvious incentive to deliver what the Minister wants in terms of his short-term policy preferences rather than advise what is in the public's long-term interest. Little wonder, perhaps, that those asking questions of PPPs have been characterized as 'critics' and as getting in the way of business. 
19. See Hodge and Bowman (2006, p. 102). They presented the 2004/05 revenues of the 'Big Four' global consulting companies (Deloitte, Ernst \& Young, KPMG and PwC as totalling US\$71.1 billion). And assuming that the big four firms account for 45 per cent of the global market (Consulting Times, 2004), and that revenues have been increasing at say 4 per cent per year since then, the estimate for global consulting revenues for 2009/10 would be around US\$192 billion.

20. Perhaps the outlier here was the USA, which facilitated desired development directions more through private sector incentives. This view, however, is also contestable, in that there are clearly disparities between the often-heard rhetoric of private sector entrepreneurship and small government, and the reality of a large US government that has historically provided strong subsidies to a range of military, industrial and developmental activities.

21. We could also add environmental goals to this list.

22. In effect, therefore, this framework also evaluates alternatives in terms of equity (i.e. the distribution of impacts).

\section{References}

Allan, J.R. (1989), Public-Private Partnerships, Institute for Public Policy, Working Paper Series, Yale University.

Berg, S., M. Pollitt and M. Tsuji (eds) (2002), Private Initiatives in Infrastructure: Priorities, Incentives and Performance, Cheltenham, UK and Northampton, MA, USA: Edward Elgar.

Blanc-Brude, F., H. Goldsmith and T. Valila (2007), Public-Private Partnerships in Europe: An Update, Economic and Financial Report 2007/03, European Investment Bank, p. 24.

Campbell, G. (2001), 'Public Private Partnerships - A Developing Market?', Melbourne, unpublished.

Consulting Times (2004), accessed at www.consulting times.com.

Davies, J. (2008), 'Alliance contracts and public sector governance', $\mathrm{PhD}$ thesis, Griffith University, August, unpublished.

Ernst \& Young (2007), The Road Ahead: Future of PPP in Australian Road Infrastructure, Ernst \& Young Australia.

Grimsey, D. and M. Lewis (2004), Public-Private Partnerships: The Worldwide Revolution in Infrastructure Provision and Project Finance, Cheltenham, UK and Northampton, MA, USA: Edward Elgar.

Heald, David (2003), 'Value for money tests and accounting treatment in PFI schemes', Accounting, Auditing and Accountability Journal, 16 (3), 342-71.

HM Treasury (2003), PFI: Meeting the Investment Challenge, London: The Stationery Office.

Hodge, G.A. (2000), Privatisation: An International Review of Performance, Boulder, CO: Perseus Books/Westview Press.

Hodge, G.A. (2006), 'Public-private partnerships and legitimacy', University of New South Wales Law Journal, Forum, 29 (3), 318-27.

Hodge, G.A. and D.M. Bowman (2006), 'The consultocracy: the business of reforming government', in Graeme Hodge (ed.), Privatization and Market Development: Global Movements in Public Policy Ideas, Cheltenham, UK and Northampton, MA, USA: Edward Elgar, pp. 97-126.

Hodge, G.A. and C. Greve (2007), 'Public-private partnerships: an international performance review', Public Administration Review, 67 (3), 545-58.

IFSL Research (2008), PPPs in the UK \& PPP in Europe 2008, International Financial Services, London, 4 March, 'PPPs in partnership with City of London and UK Trade and Investment', www.ifsl.org.uk/research, accessed 13 January 2009.

Jigsaw Productions (2005), Enron: The Smartest Guys in the Room, public release feature film.

Koppenjan, J.F.M. (2005), 'The formation of public-private partnerships. Lessons from 


\section{International handbook on public-private partnerships}

nine transport infrastructure projects in the Netherlands', Public Administration, 83 (1), $135-57$.

Lindblom, C.E. (1959), 'The science of muddling through', Public Administration Review, 19, (Spring), 79-88.

Linder, S. (1999), 'Coming to terms with the public-private partnership: a grammar of multiple meanings', The American Behavioural Scientist, 43 (1), 35-51.

McIntosh, K., J. Shauness and R. Wettenhall (1997), Contracting Out in Australia: An Indicative History, Canberra: Centre for Research in Public Sector Management, University of Canberra.

OECD (2008), Public-Private Partnerships: In Pursuit of Risk Sharing and Value for Money, Paris: OECD.

Osborne, S. (ed.) (2001), Public-Private Partnerships: Theory and Practice in International Perspective, New York: Routledge.

Parker, D. (2004), 'The UK's privatisation experiment: the passage of time permits a sober assessment', CESifo Working Paper 1126, Cranfield University.

PricewaterhouseCoopers (2005), Delivering the PPP Promise. A Review of PPP Issues and Activities, available online at www.pwc.com/, viewed 26 November 2008.

Rayner, S. (2004), 'The novelty trap: why does institutional learning about new technologies seem so difficult?', Industry and Higher Education, 18 (6), 349-56.

Savas, E.S. (2000), Privatization and Public-Private Partnerships, New York: Chatham House Publishers and Seven Bridges Press.

Van Ham, H. and J. Koppenjan (2001), 'Building public-private partnerships: assessing and managing risks in port development', Public Management Review, 4 (1), 593-616.

Weihe, G. (2005), 'Public-Private Partnerships: Addressing a Nebulous Concept', Working Paper no. 16, Denmark: International Centre for Business and Politics, Copenhagen Business School.

Weimer, D. and A. Vining (2004), Policy Analysis: Concepts and Practice, 4th edn, Upper Saddle River, NJ: Prentice Hall.

Wettenhall, R. (2003), 'The rhetoric and reality of public-private partnerships', Public Organisation Review: A Global Journal, 3, 77-107.

Wettenhall, R. (2005), 'The public-private interface: surveying the history', in Graeme Hodge and Carsten Greve (eds), The Challenge of Public-Private Partnerships: Learning from International Experience, Cheltenham, UK and Northampton, MA, USA: Edward Elgar.

Zarco-Jasso, H. (2005), 'Public-private partnerships: a multidimensional model for contracting', International Journal of Public Policy, 1 (1-2), 22-40. 